\title{
Some Biochemical Changes in Brain and Blood of Experimental Rats Resulting From Monosodium Glutamate (MSG) Administration
}

\author{
Ayman A. Wagih \\ Medical Biochemistry Department, Faculty of Medicine - \\ Tanta University
}

\begin{abstract}
Objective: Monosodium glutamate (MSG) is one of the commonest food additives in the world and it is a commonly used flavor enhancer. In recent years MSG consumption has increased as flavoring in cooking. Interestingly, little is known about its effects on oxidative stress and some metabolic changes. Aim of the study: The aim of this study was to elucidate the effect of oral ingestion of MSG on some biochemical changes in the brain and blood of experimental rats to demonstrate the adverse effects of that widely used flavor enhancer. Materials and methods: This study was carried out on 50 white albino rats which were divided into two equal groups; control group and MSG treated group. All groups were subjected to estimation of serum lipid profile, free fatty acids (FFs) and malondialdehyde (MDA) levels. Also brain tissue levels of L-glutamate, gamma amino butyric acid (GABA) and MDA were measured for all groups. Results: The present study showed that oral feeding of MSG significantly increased final body weight, visceral fat weight, impaired glucose tolerance and a state of dyslipidemia with an increased serum free fatty acid level. Significant increase of both serum and brain MDA tissue levels were also documented. MSG-treated group also showed significant increase of brain $L$. glutamate and significant decrease of brain gamma amino butyric acid (GABA) levels as compared to the control. Conclusion: On the basis of these results it could be concluded that MSG may be an inductive factor of several biochemical and metabolic alterations taking place in healthy subjects, which clearly must contribute to the development of obesity, decreased glucose tolerance and some excitotoxic effects. Recommendations: The present findings are alarming, and throw doubts upon the unscrupulousness of current use of the flavoring agent MSG in fast processed and canned foods. Much work is still to be performed to determine other adverse effects on other organs.
\end{abstract}

Key Words: Monosodium glutamate (MSG), malondialdehyde (MDA) and gamma amino butyric acid (GABA) and free fatty acids (FFs).

\section{INTRODUCTION}

Monosodium glutamate (MSG) is sodium salt of naturally occurring non-essential L form of glutamic acid, it is one of the main flavor enhancers which is widely used in the preparation of large percentage of canned, frozen and prepared foods, especially soups, sauces and 
broths $^{(\mathbf{1}, 2)}$. Recently, monosodium glutamate consumption has increased throughout the world as flavoring in cooking and to increase palatability and food selection in a meal ${ }^{(3,4)}$. The use of MSG has been steadily increasing worldwide over the past years, somehow paralleling the rising incidence of the metabolic syndrome and fatty liver disease ${ }^{\mathbf{( 5 )}}$.

Human cerebral cortical activity may be under the influence of a large number of neuroactive substances, These substances are important for the normal integrity of the normal function of the CNS system which controls a variety of physiological, behavioral, and endocrinal function ${ }^{(6)}$.

Glutamic acid is the most abundant of a group of endogenous amino acids in the mammalian central nervous system and has become widely accepted as a major neurotransmitter in the vertebrate central nervous system ${ }^{(7)}$. L Glutamate is the major excitatory neurotransmitter in the brain, exists in the extracellular fluid only in very small concentrations, and clearly plays a pivotal role in the formation of synapses and neuronal circuitry, in neuronal differentiation, migration and survival in the developing brain $^{(\mathbf{8 , 9})}$. Glutamate receptors are present in the central nervous system, mouth, lungs, intestines, muscle, and other "peripheral" locations. Brains have many receptors for glutamic acid $(\mathbf{1 0 , 1 1 )}$. In the brain it is an important mediator of sensory information, motor coordination, emotions and cognition including formation and retrieval of the memory and adaptation to the environment ${ }^{(12,13)}$.
GABA is the principal inhibitory neurotransmitter in the mammalian central nervous system. GABAergic pathways sub-serve a variety of functions, including regulation of brain excitability, modulation of respiratory neural inputs, motor control, and information processing within and between brain regions ${ }^{(\mathbf{1 4 , 1 5})}$. MSG has neurotoxic effects resulting in brain cell damage, retinal degeneration, endocrine disorders and some pathological conditions such as stroke, epilepsy, neuropathic pain, schizophrenia, anxiety, depression and degenerative disorders ${ }^{(\mathbf{1 6})}$.

Although MSG was reported to have broad toxic effects interestingly little is known about the effects of MSG added to dry food on oxidative stress and metabolic parameters ${ }^{(17,18)}$. Oxidative stress represents an imbalance between the production and the effects of reactive oxygen species and a biological system's ability to readily detoxify the reactive intermediates or to repair the resulting damage ${ }^{(19)}$.

So, the present study was conducted to elucidate the effect of oral ingestion of monosodium glutamate on some biochemical changes in the brain and blood of experimental rats as it is widely used as flavor enhancer.

\section{MATERIALS \& METHODS}

This study was carried out on 50 female white albino rats (weight 200250 grams) that were divided into two equal groups; Group I (control group), which were given a standard diet for 45 days and group II, which were given a standard diet and monosodium 
glutamate (MSG) orally by gastric tube in a dose of $(0.4 \mathrm{~g} / \mathrm{kg}$ body weight) for 45 days. The doses of MSG were chosen on the basis of the previous studies ${ }^{(20)}$. All experiments were carried out according to the guidelines of the Ethical Committee of Tanta University, Faculty of Medicine.

\section{Sample collection:}

All rats were sacrificed and blood samples were collected. Sera were separated and stored in aliquots at -70 ${ }^{\circ} \mathrm{C}$ till used for different estimations. Then, the abdomen and the thorax were opened; visceral fats were dissected, washed with saline and weighed. The brains were removed carefully, washed three times in ice cold saline to remove extraneous materials, blotted individually on ashfree filter paper, and then divided into two specimens. Specimens were stored at $-70 \quad{ }^{\circ} \mathrm{C}$ till used for preparation of tissue homogenates.

\section{Preparation of brain tissue} homogenates:

Specimens were weighted and homogenized with a PotterElvenhjem tissue homogenizer (20-30 up and down strokes). One part was homogenized in ice-cold saline and centrifuged at $10,000 \mathrm{rpm}$ for 10 minutes at $0^{\circ} \mathrm{C}$ for estimation of $\mathrm{L}$ glutamate and gamma amino butyric acid (GABA) levels and the second was homogenized in potassium phosphate buffer $10 \mathrm{mM}(\mathrm{pH} 7.4)$ and centrifuged at $7,700 \times \mathrm{g}$ for 30 minutes at $4^{\circ} \mathrm{C}$ for estimation of malondialdehyde (MDA) level, Homogenate was centrifuged at 7,700 $\mathrm{x} g$ at $4^{\circ} \mathrm{C}$ for 30 minutes and the resultant supernatant was assayed for the different estimations.
All groups were subjected to the measurements of the following;

1. Lipid profile including serum levels of triacylglycerol (TAG) (21), total cholesterol (TC) ${ }^{(22)}$, high density lipoprotein cholesterol (HDL-C) ${ }^{(23)}$, and low density lipoprotein cholesterol (LDL-C) level (24). By enzymatic colorimetric method using commercial kits supplied by Biomed Diagnostics, Egypt.

2. Oral glucose tolerance test: The test was done by making the rats fast for 4 hours and then the blood was taken by puncture of rat tail vein. Glucose level was determined by glucocheck method. Then the rats were fed glucose by gastric tube at a dose of $2 \mathrm{~g} / \mathrm{kg}$ body weight. The glucose level was then measured again at 30, 60, 90 and 120 minutes.

3. Spectrophotometric determination of free fatty acids (FFAs) level: Free fatty acids were determined in serum by a colorimetric method as described by Arnold 1965 based on the ability of free fatty acids to form copper salts extractable with chloroform and the absorbance was read at $600 \mathrm{~nm}$ using Pharmacia Biotech spectrophotometer (Model No. ultrospec. 1000) ${ }^{(25)}$.

4. Spectrophotometric determination of serum and tissue MDA levels: By colorimetric method using commercial kit supplied by Bio Diagnostic, Egypt. This method depends on the formation of MDA as an end product of lipid peroxidation which reacts with 
thiobarbituric acid producing thiobarbituric acid reactive substance (TBARS), a pink chromogen, which can be measured spectrophotometrically at $532 \mathrm{~nm}^{(26,27)}$.

5. Fluorometric determination of brain L- glutamate level: LGlutamate level was measured using the fluorometric method of Graham and Aprison ${ }^{(28)}$, which depend on determination of glutamate concentration in the samples was detected by fluorometric detection of NADH resulting from the reaction of glutamate and $\mathrm{NAD}^{+}$to $\alpha$ ketoglutarate and NADH, catalyzed by glutamate dehydrogenase. Glutamate concentration is directly proportional to the concentration of NADH in the reaction ${ }^{(28)}$.

6. Fluorophotometric determination of brain tissue GABA level: Gamma amino butyric acid (GABA) content was estimated according to the method of Lowe et al. (1958) ${ }^{(29)}$.

\section{RESULTS}

Table 1: Statistical comparison between the studied groups as regards lipid profile.

\begin{tabular}{|l|l|l|l|}
\hline Parameter & Group I & Group II & p. value \\
\hline Triacylglycerol $(\mathrm{TAG})$ level $(\mathrm{mg} / \mathrm{dl})$ & $150.60 \pm 6.84$ & $256.44 \pm 32.10$ & $<0.001^{*}$ \\
\hline Total cholesterol $(\mathrm{TC})$ level $(\mathrm{mg} / \mathrm{dl})$ & $103.04 \pm 9.48$ & $168.12 \pm 20.39$ & $<0.001^{*}$ \\
\hline HDL cholesterol $(\mathrm{mg} / \mathrm{dl})$ & $39.68+6.54$ & $27.42+3.98$ & $<0.001^{*}$ \\
\hline LDL cholesterol $(\mathrm{mg} / \mathrm{dl})$ & $33.11+13.92$ & $89.51+19.13$ & $<0.001^{*}$ \\
\hline
\end{tabular}

Group I: Control group (no=25). Group II: MSG treated group (no=25).

Table 2: Statistical comparison between the two studied groups as regards oral glucose tolerance test

\begin{tabular}{|l|l|l|l|}
\hline & Group I & Group II & p. value \\
\hline Fasting & $84+3.04$ & $95.28+2.90$ & $<0.05^{*}$ \\
\hline $30 \mathrm{~min}$. & $95.92+2.87$ & $105.40+2.85$ & $<0.05^{*}$ \\
\hline $60 \mathrm{~min}$. & $106.36+2.79$ & $115.52+3.02$ & $<0.05^{*}$ \\
\hline $90 \mathrm{~min}$. & $123.5+4.03$ & $133.04+4.80$ & $<0.05^{*}$ \\
\hline $120 \mathrm{~min}$. & $114.72+3.84$ & $130.48+5.05$ & $<0.05^{*}$ \\
\hline
\end{tabular}

Group I: Control group (no=25). Group II: MSG treated group (no=25). 


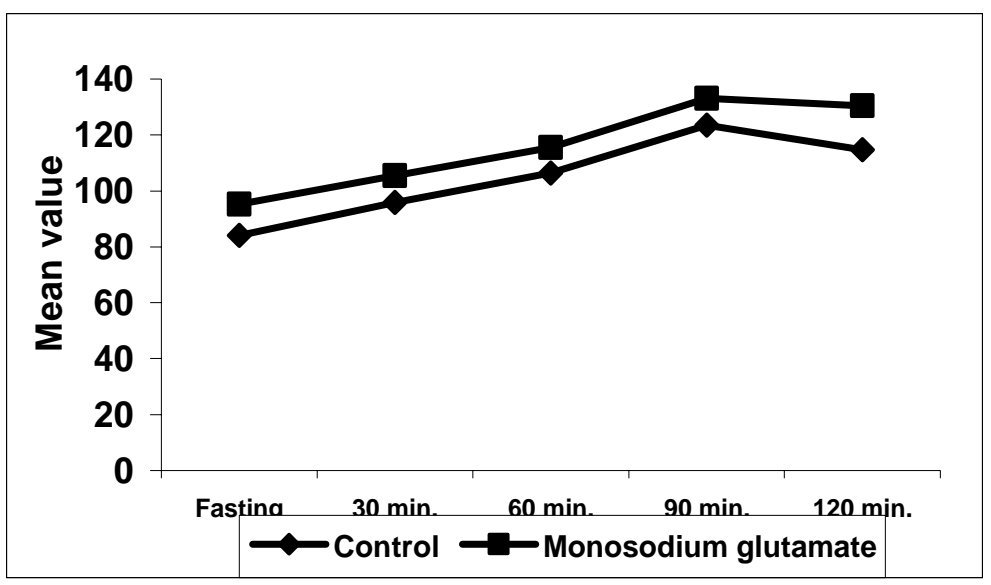

Fig. 1: Comparison between the two studied groups as regards plasma glucose levels (mg./dl) during oral glucose tolerance test.

Table 3: Comparison between the two studied groups as regards body weight (g)

\begin{tabular}{|l|l|l|l|}
\hline & Group I & Group II & p. value \\
\hline Initial weight $(\mathrm{g})$ & $216.40+14.68$ & $225+14.50$ & $<0.05^{*}$ \\
\hline 2 weeks $(\mathrm{g})$ & $224.20+14.48$ & $244+17.38$ & $<0.05^{*}$ \\
\hline 4 weeks $(\mathrm{g})$ & $232+14.79$ & $258.60+20.28$ & $<0.05^{*}$ \\
\hline 6weeks $(\mathrm{g})$ & $239.60+15.47$ & $280+17.01$ & $<0.001^{*}$ \\
\hline
\end{tabular}

Group I: Control group (no=25). $\quad$ Group II: MSG treated group (no=25).

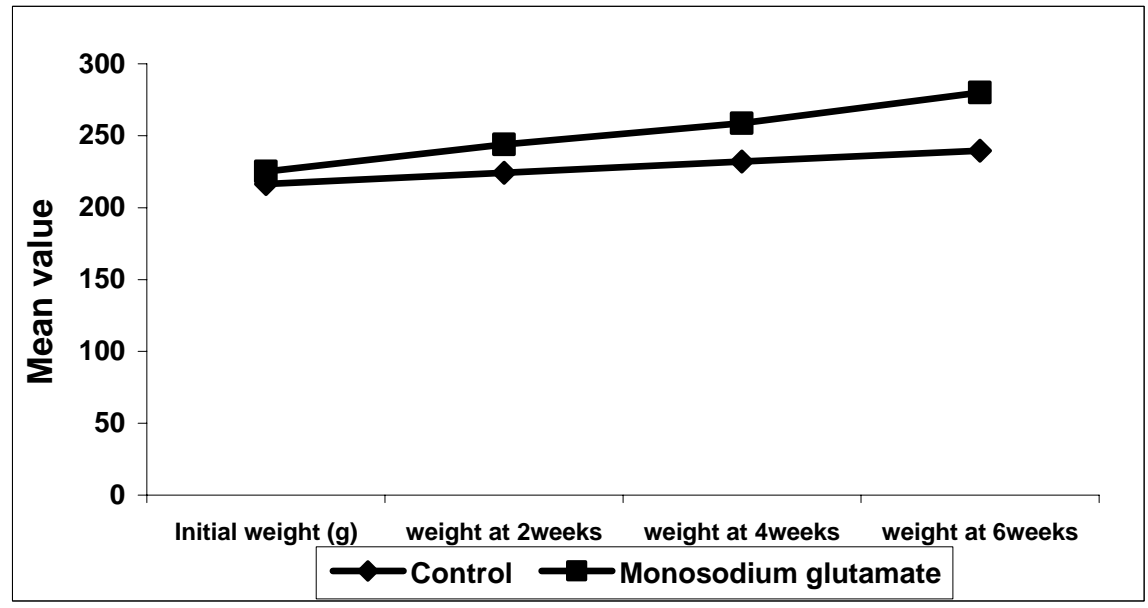

Fig. 2: Comparison between the two studied groups as regards body weight (g). 
Table 4: Comparison between the two studied groups as regards visceral fat weight (g)

\begin{tabular}{|l|l|l|}
\hline Visceral fat weight $(\mathbf{g})$ & Group I & Group II \\
\hline Mean +SD & $4.80+0.77$ & $11.49+1.74$ \\
\hline p. value & $<0.001^{*}$ & \\
\hline
\end{tabular}

Group I: Control group (no=25). Group II: MSG treated group (no=25).

Table 5: Statistical comparison between the two studied groups as regards serum FFAs (mmol/L) and MDA (nmol/ml) level .

\begin{tabular}{|l|l|l|l|}
\hline & Group I & Group II & p. value \\
\hline Serum FFAs & $86.60 \pm 15.68$ & $200.42 \pm 15.15$ & $<0.001^{*}$ \\
\hline Serum MDA & $7.68+1.05$ & $28.97+7.10$ & $<0.001^{*}$ \\
\hline
\end{tabular}

Group I: Control group (no=25). $\quad$ Group II: MSG treated group (no=25).

Table 6: Comparison between the two studied groups as regards brain tissue levels of MDA (nmol/g. tissue), L. glutamate ( $\mu \mathrm{m} / \mathrm{g}$. tissue) and GABA ( $\mu \mathrm{g} / \mathrm{g}$. tissue).

\begin{tabular}{|l|l|l|l|}
\hline & Group I & Group II & p. value \\
\hline MDA & $22.19 \pm 1.43$ & $69.93 \pm 6.44$ & $<0.001^{*}$ \\
\hline L. glutamate level & $147.85 \pm 26.99$ & $229.26 \pm 28.85$ & $<0.001^{*}$ \\
\hline GABA level & $147.85 \pm 26.99$ & $229.26 \pm 28.85$ & $<0.001^{*}$ \\
\hline
\end{tabular}

Group I: Control group (no=25). Group II: MSG treated group (no=25).

Table 7: Correlation studies between brain MDA level (nmol/ g. tissue) \& both brain L. glutamate $(\mu \mathrm{m} / \mathrm{g}$. tissue) and brain GABA $(\mu \mathrm{g} / \mathrm{g}$. tissue) levels in MSG treated group.

\begin{tabular}{|l|l|l|l|}
\hline \multicolumn{2}{|l|}{} & L. glutamate & GABA \\
\hline \multirow{2}{*}{ MDA } & $\mathrm{r}$ & 0.652 & -0.558 \\
\cline { 2 - 4 } & P-value & $<0.001^{*}$ & $<0.001^{*}$ \\
\hline
\end{tabular}

Table 7: Correlation studies between both brain GABA (nmol/g. tissue) \& brain L. glutamate $(\mu \mathrm{m} / \mathrm{g}$. tissue) levels in MSG treated group.

\begin{tabular}{|l|l|l|}
\hline \multicolumn{2}{|l|}{} & L. glutamate \\
\hline \multirow{2}{*}{ GABA } & r & -0.756 \\
\cline { 2 - 3 } & P-value & $<0.001 *$ \\
\hline
\end{tabular}


Table 1 showed a state of dyslipidemia with significant increase of serum triacylglycerol, total cholesterol and LDL-cholesterol ( $\mathrm{P}<$ $0.001)$ and significant decrease of serum HDL-C level in MSG treated group (group II) as compared to group I $(\mathrm{P}<0.001)$.

Table (2) and figures (1) showed comparison between the two studied groups as regards glucose tolerance test. Significantly higher plasma glucose levels during fasting and the following four samples after the glucose load were noticed in rats of group II compared to their levels in group I $(\mathrm{P}<0.05$ for each). Table (3) and figures (2) showed comparison between body weight $(\mathrm{g})$ of the two studied groups starting from the initial weight to their weight at 6 weeks separated by 2 weeks interval. There was significant increase of body weight by the end of $6^{\text {th }}$ weeks in group II compared to group I $(\mathrm{P}<0.001)$. Also, there was significant increase of visceral fat weight in group II compared to group I $(\mathrm{P}<0.001)$, table (4). Both serum FFAs (mmol/l.) and MDA (nmol/ml) levels showed significant increase in group II compared with its level in group I ( $\mathrm{P}<0.001)$, table (5).

In the present study, brain tissues showed significant increase of MDA as well as L. glutamate $(\mathrm{P}<0.001)$ and significant decrease $(\mathrm{P}<0.001)$, of GABA levels in group II as compared to group I, table (5).

Correlation studies in the present study showed significant positive correlation between brain MDA level and brain L. glutamate level $(r=0.652, \mathrm{P}<0.001)$. Negative correlation was found between both
MDA and GABA brain tissue levels ( $\mathrm{r}$ $=-0.558, \mathrm{p}<0.001)$. Negative correlation was found between brain GABA level and brain L. glutamate level in MSG treated group ( $\mathrm{r}=$ $0.756, \mathrm{P}<0.001)$. Also there was positive correlation between both serum and brain MDA levels in MSG treated group $(\mathrm{r}=0.815, \mathrm{P}<0.001)$, and also between body weight and visceral fat weight in MSG treated group $(r=0.877, \mathrm{P}<0.001)$.

\section{DISCUSSION}

The use of monosodium glutamate (MSG) has been steadily increasing worldwide over the past years, somehow paralleling the rising incidence of the metabolic syndrome and fatty liver disease (5). Monosodium glutamate induces hyperlipidemia, hyperglycemia and oxidative stress in blood, erythrocyte, liver and heart, a well-known risk factors for atherosclerosis ${ }^{\mathbf{( 2 0 )}}$.

Although MSG was reported to have broad toxic effects on different body organs of human and experimental animals, yet it is still widely used in Eastern and Western diets. Interestingly, little is known about the effects of MSG added to dry food on oxidative stress and metabolic parameters ${ }^{(17,18)}$.

So, the present study was conducted to elucidate the effect of oral ingestion of monosodium glutamate on some biochemical changes in the brain and blood of experimental rats as it is widely used as flavor enhancer.

The results of present study showed significantly higher plasma glucose levels during fasting and the 
subsequent samples during the glucose tolerance test in MSG treated group compared to the control group. These results are in agreement with the results of Nagata et al., ${ }^{(30)}$, Nakanishi et al. ${ }^{(31)}$ and Sasaki et al. (32) who found significantly higher blood glucose levels and impaired glucose tolerance curve in MSG treated group as compared to the control group. They also reported that administration of MSG induced obesity, diabetes mellitus, and liver lesions resembling those of nonalcoholic fatty liver disease/nonalcoholic steatohepatitis with more severe conditions by increasing the dose of MSG.

Similarly, Zhang et al. ${ }^{(33)}$, Sasaki et al. ${ }^{(34)}$ and Nardelli et al. ${ }^{(35)}$ reported a decrease in glucose tolerance and the appearance of insulin resistance in MSG treated animals.

The present study also showed a state of dyslipidemia in MSG treated group with significant increase of serum levels of total cholesterol, triacylglycerol and LDL-C and significant decrease of HDL-C level. Also, serum free fatty acids (FFAs) level showed significant increase in MSG- treated rats when compared to control group.

These results are in harmony with those obtained by Zhang et al. ${ }^{(33)}$, Singh et al. ${ }^{(36)}$ and Sasaki et al. ${ }^{(34)}$ who found that oral ingestion of MSG induces a state of dyslipidemia with significant increase of serum levels of total cholesterol, triacylglycerol, LDL-C ,VLDL-C, free fatty acids and significant decrease of HDL-C.

The present study also showed significant increase of total body and visceral fat weights in MSG treated group as compared to the control group. These results are in harmony with other previous studies of Nagata et al. ${ }^{(30)}$ and Sasaki et al. ${ }^{(32)}$ who reported significant increase of total body weight and BMI of MSG-treated mice compared with the normal mice, although food intake was equal. They documented that the main cause of obesity was not thought to be a disturbance of appetite, suggesting that obesity is caused by a decrease in energy metabolism, secondary to brown adipose tissue (37) and autonomic nerve dysfunction (38). Dolnikof et al. ${ }^{(39)}$ proposed that the presence of an enhanced insulin sensitivity in MSG rats is responsible for the decreased lipolytic activity and enhanced glucose uptake. In addition, the enhanced lipogenesis and glycerol reutilization seen in their adipose tissue disturbs the normal balance between fat depots breakdown and accumulation in favor of the latter. Thus, the massive accumulation of adipose tissue in those animals seems to be related to an imbalance between the signals which control both the lipolytic response and the lipogenic activity.

Similarly, Sasaki et al. ${ }^{(34)}$ and Matyšková et al. ${ }^{(40)}$ reported that all mice with MSG obesity excessively accumulated subcutaneous, abdominal and gonadal fat and showed dramatically enhanced fat and body weight.

Luz et al. (41) reported that neonatal administration of monosodium glutamate to rodents leads to appearance of obesity in the adult animals, which is usually characterized by a significant increase in body fat. They have suggested that 
MSG induced obesity could be the result of a decreased metabolic rate rather than of increased food intake.

In addition, Baculikova et al. ${ }^{(42)}$ and Matyšková et al. ${ }^{(40)}$ reported that the administration of MSG to newborn rats causes the destruction of the ventromedial hypothalamic and arcuate nuclei, leading the rats to develop obesity that results from the lack of control between absorption and energy expenditure. The real mechanism by which this hypothalamic injury leads to obesity is not known, but what is known is that it is not because of increased food intake $^{(\mathbf{4 0})}$.

Afifi et al. ${ }^{(43)}$ also concluded that MSG treated pregnant rats, in spite of mild hypophagia, showed severe increase in fat/ body weight ratio. Moreover, maternal obesity in pregnancy, caused by MSG, has greater impact on offspring metabolism. They suggested that the relationship between MSG-induced damage of arcuate nucleus and the metabolic changes that produce obesity at mild hypophagia be probably occurred due to the lack of leptin receptors in arcuate nucleus and the development of leptin resistance.

Also, Collison et al. ${ }^{(44)}$ stated that MSG increased the expression of several genes implicated in adipocytes differentiation.

Induction of oxidative stress as a consequence of MSG treatment had been also reported by Onyema et al. (45). Lipid peroxidation in cellular membranes damages polyunsaturated fatty acids tending to reduce membrane fluidity, which is essential for proper functioning of the cell. MDA, an end-product of LPO induced by reactive oxygen species (ROS), is well correlated with the degree of lipid peroxidation ${ }^{(46)}$.

When lipid peroxides are formed in some organs or tissues and accumulated to certain degree, they leak from organs or tissues into the blood stream and increase lipid peroxides level in serum or the plasma. Although an increased lipid peroxides level in blood can be due to either exogenous causes or endogenous ones, an abnormal increase in lipid peroxides level is usually due to the latter, which indicates the occurrence of tissue damage in cells of some organs or tissues provoked by the diseases or xenobiotics ${ }^{(46,47)}$.

This study showed significant increase in both serum and brain malondialdehyde (MDA) levels in MSG- treated rats confirming the effect of MSG in induction of oxidative stress.

The brain contains large amounts of polyunsaturated fatty acids (PUFA), which are particularly vulnerable to free radical attacks resulting in the formation of carbon and hydroxyl radicals ${ }^{(48)}$. The latter initiates a chain reaction, ultimately generating numerous toxic reactants that rigidify membranes by crosslinking, disrupting membrane integrity and changing membrane proteins $(48,49)$.

The significant increase in serum and brain MDA levels observed in MSG- treated groups in the present study is in agreement with the results of Pavlovic et al. ${ }^{(17)}$; Egbuonu et al. (50) and Vinodini et al. (51) who reported an increased the serum MDA level, a marker of lipid peroxidation in 
MSG-treated rats by over two-folds, which may be due to the increased generation of reactive oxygen species (ROS) by MSG.

Farombi et al., (52) also documented that a significant induction of lipid peroxidation in the liver, kidney and brain of rats treated with MSG might be due to oxidative stress induced by MSG in those tissues.

Brain L-Glutamate level in the present study showed significant increase in MSG- treated rats compared to the control group, a finding which is in agreement with the results of Manivasagam and Subramanian (53) who found significant increase in the brain Lglutamate level of rats treated with MSG.

López-Pérezet et al. ${ }^{(54)}$ also reported that MSG administration prompts an immediate increase of cerebral glutamate tissue level and also elevates glutamate extracellular levels in plasma and other tissues, where the amount reached depends on administration pathway, doses, age and the animal model used.

The pharmacokinetics of MSG depends on its route of administration which, in turn determine its effects on extracellular brain glutamate concentrations. When glutamate is consumed orally, its effects on the brain are buffered by metabolism in the gastrointestinal tract. Extrusion from the brain by active blood-brain transport systems, and local mechanisms mediating its uptake and metabolism in brain; these cause brain extracellular glutamate concentrations to remain relatively stable. The mechanism of MSG neurotoxic effects has been attributed to a prolonged increase in extracellular glutamate concentrations ${ }^{(55)}$.

Similarly, under normal conditions, the glutamate carrier through the blood-brain barrier (BBB) is virtually saturated at physiological plasma glutamate concentrations ${ }^{(56)}$. Moreover, in physiological conditions the influx of glutamate across the BBB is much lower than its efflux from the brain ${ }^{(57)}$. Therefore, the increase in plasma glutamate levels after systemic MSG administration may not by itself cause the increase in extracellular brain glutamate levels. This increase may also reflect damage to mechanisms operating at the level of the BBB; increased permeability after systemic MSG resulting from the massive increase in plasma osmolarity (58)

Our study also showed significant decrease of brain gamma amino butyric acid (GABA) level in MSGtreated rats. This finding is in agreement with the result of Sepúlveda et al. ${ }^{(59)}$ who reported that MSG neurotoxicity reduces the activity of glutamic acid decarboxylase (GAD) in some areas of the CNS and, consequently, the content of GABA.

\section{CONCLUSION}

On the basis of these results it could be concluded that oral monosodium glutamate used as a food additive may be an inductive factor of several biochemical and metabolic alterations, which clearly must contribute to the development of obesity, impaired glucose tolerance and some excitotoxic effects. 


\section{RECOMMENDATIONS}

The present findings are alarming, and throw doubts upon the unscrupulousness of current use of the flavoring agent MSG in fast processed and canned foods. Much work is still to be performed to determine other adverse effects on other organs.

\section{REFERENCES}

1. Geha RS, Beiser A, Ren C et al. (2000): Review of alleged reaction to MSG and outcome of a multicentre double blind placebo-controlled study. J. Nutr., 130(4S Suppl.1): 1058s-1062s.

2. Geha RS, Beiser A, Ren $C$ et al. (2000): Multicenter, doubleblind, placebo-controlled, multiple-challenge evaluation of reported reactions to monosodium glutamate. J. Allergy Clin. Immunol., 106(5): 973- 980.

3. Diniz YS, Faine LA, Galhardi CM et al. (2005): Monosodium glutamate in standard and highfiber diets: metabolic syndrome and oxidative stress in rats. Nutrition 21(6):749- 755.

4. Taylor-Burds CC, Westburg AM, Wifall TC et al. (2004): Behavioral comparisons of the tastes of L-alanine and monosodium glutamate in rats. Chem Senses., 29(9):807- 814.

5. Hermanussen $M$, Garcia AP, Sunder M et al. (2006): Obesity, voracity, and short stature: the impact of glutamate on the regulation of appetite. Eur. J. Clin. Nutr., 60(1): 25- 31.
6. Greengard P. (2001): The neurobiology of slow synaptic transmission Science 294: 10241030.

7. Meldrum BS (2000): Glutamate as a neurotransmitter in the brain: review of physiology and pathology. Nutr., 130(4S Suppl.): 1007S-15S.

8. Jinap $S$ and Hajeb $P$ (2010): Glutamate. Its applications in food and contribution to health. Appetite 55(1): 1- 10.

9. Sano C (2009): History of glutamate production. Am J. Clin. Nutr., 90(3): 728-732.

10. Schlichtherle-Cerny $H$ and Amado R (2002): Analysis of taste-active compounds in an enzymatic hydrolyzate of deamidated wheat gluten. J. Agric. Food Chem., 50(6): 15151522.

11. Waggas AM (2009):

Neuroprotective evaluation of extract of ginger (Zingiber officinale) root in monosodium glutamate-induced toxicity in different brain areas male albino rats. Pak. J. Biol. Sci., 12 (3): 201- 212.

12. Plaitakis $A$ and Zaganas $I$ (2001): Regulation of human glutamate dehydrogenases: Implications for glutamate, ammonia and energy metabolism in brain. J. of Neuroscience Research 66 (5): 899-908.

13. Kelly A and Stanley CA (2001): Disorders of glutamate metabolism. Mental retardation and developmental disabilities Research reviews 7(4): 287-295.

14. Mody I and Pearce RA (2004): Diversity of inhibitory 
neurotransmission through

GABA (A) receptors. Trends Neurosci., 27(9): 569- 575

15. Bowery NG and Enna SJ (2000): $\gamma$-aminobutyric acid (B) receptors: first of the functional metabotropic heterodimers. J. Pharmacol. Exp. Ther., 292(1): 27.

16. Ninomiya $K$ (2001): An overview of recent research on MSG. Sensory applications and safety. Food Australia 53: 546549.

17. Pavlovic V, Pavlovic D, Kocic G et al. (2007): Effect of monosodium glutamate on oxidative stress and apoptosis in rat thymus. Mol. Cell Biochem., 303(1-2): 161- 166.

18. Valko M, Leibfritz D, Moncol J et al. (2007): Free radicals and antioxidants in normal physiological functions and human disease. Int. J. Biochem. Cell Biol., 39(1): 44- 84.

19. Urso ML and Clarkson $P M$ (2003): Oxidative stress, exercise, and antioxidant supplementation. Toxicology 189(1-2):41- 54.

20. Kuldip $S$ and Ahluwalia $P$ (2007): Studies on the effect of MSG administration on glutathione and its metabolizing enzymes in cardiac tissue of adult male mice. SFRR India Bull., 7: 22- 27.

21. Fossati $P$ and Prencipe $L$ (1982): Serum triglycerides determined colorimetrically with an enzyme that produces hydrogen peroxide. Clin. Chem., 28(10): 2077- 2080.
22. Richmond W (1973): Enzymatic determination of cholesterol. Clin. Chem., 19: 1350- 1356.

23. Grove TH (1979): Effect of reagent $\mathrm{pH}$ on determination of HDL cholesterol by precipitation with sodium phosphotungestate magnesium. Clin. Chem., 25(4): 560-4.

24. Wieland $H$ and Seidel D (1983): A simple specific method for precipitation of low density lipoproteins. J. Lipid Res., 24(7): 904- 909.

25. Arnold A (1965): Semiautomated method for the colorimetric determination of plasma free fatty acids. J. Lipid Res., 6: 307- 312.

26. Satoh K (1978): Serum lipid peroxide in cerebrovascular disorders determined by a new colorimetric method. Clinica Chimica Acta 90 (1): 37- 43.

27. Ohkawa H, Ohishi $N$ and Yagi K (1979): Assay for lipid peroxides in animal tissues by thiobarbituric acid reaction. Anal. Biochem., 95(2): 351- 358.

28. Graham Lt Jr and Aprison MH (1966): Fluorometric determination of aspartate, glutamate, and gamma-amino butyrate in nerve tissue using enzymic methods. Anal. Biochem., 15(3): 487- 497.

29. Lowe IP, Robins $E$ and Eyerman GS (1958): The fluorometric measurement of glutamic acid decarboxylase and its distribution in brain. J. Neurochem., 3(1): 8- 18.

30. Nagata $M$, Suzuki $W$, Iizuka $S$ et al. (2006): Type 2 diabetes mellitus in obese mouse model 
induced by monosodium glutamate. Exp. Anim., 55: 10915.

31. Nakanishi Y, Tsuneyama $K$, Fujimoto $M$ et al. (2008): Monosodium glutamate (MSG): a villain and promoter of liver inflammation and dysplasia. J. Autoimmun., 30(1- 2): 42-50.

32. Sasaki Y, Suzuki W, Shimada T et al. (2009): Dose dependent development of diabetes mellitus and non-alcoholic steatohepatitis in monosodium glutamateinduced obese mice. Life Sci., 85(13-14): 490- 498.

33. Zhang $N$, Huan $Y$, Huang $H$ et al. (2010): Atorvastatin improves insulin sensitivity in mice with obesity induced by monosodium glutamate. Acta Pharmacologica Sin., 31(1): 35- 42.

34. Sasaki Y, Shimada T, Iizuka S et al. (2011): Effects of bezafibrate in non-alcoholic steatohepatitis model mice with monosodium glutamate- induced metabolic syndrome. European J. of Pharmacol., 662(1-3): 1- 8 .

35. Nardelli TR, Ribeiro RA, Balbo SL et al. (2011): Taurine prevents fat deposition and ameliorates plasma lipid profile in monosodium glutamate-obese rats. Amino Acids 41(4): 901908.

36. Singh K, Sharma J, Kaur A et al. (2011): Alteration upon oral ingestion of monosodium glutamate in various lipid and lipoprotein fractions in serum of adult male rat. J. Life Sci., 3(1): 17- 21 .

37. Tsukahara F, Uchida Y, Ohba K et al. (1998): The effect of acute cold exposure and norepinephrine on uncoupling protein gene expression in brown adipose tissue of monosodium glutamate-obese mice. Jpn. J. Pharmacol., 77(3): 247- 249.

38. Yasuda T, Masaki T, Kakuma $T$ et al. (2004): Hypothalamic melanocortin system regulates sympathetic nerve activity in brown adipose tissue. Exp. Biol. Med., (Maywood) 229(3): 235239.

39. Dolnikof M, Martín-Hidalgo A, Machado UF et al., (2001): Decreased lipolysis and enhanced glycerol and glucose utilization by adipose tissue prior to development of obesity in monosodium glutamate treatedrats. Int. J. Obes. Relat. Metab. Disord., 25(3): 426- 433.

40. Matyšková $R$, Maletínská $L$, Maixnerová J et al. (2008): Comparison of the obesity phenotypes related to monosodium glutamate effect on arcuate nucleus and/or the high fat diet feeding in $\mathrm{C} 57 \mathrm{Bl} / 6$ and NMRI mice. Physiol. Res., 57(5): 727- 734.

41. Luz J, Pasin VP, Silva DJ, et al. (2010): Effect of food restriction on energy expenditure of monosodium glutamate-induced obese rats. Ann. Nutr. Metab., 56(1): 31-35.

42. Baculikova M, Fiala R, Jezova $D$ et al. (2008): Rats with monosodium glutamate-induced obesity and insulin resistance exhibit low expression of Gai2 G-protein. Gen. Physiol. Biophys., 27(3): 222- 226. 
43. Afifi $M M$ and Abbas AM (2011): Monosodium glutamate versus diet induced obesity in pregnant rats and their offspring. Acta Physiol. Hungarica 98 (2):177- 188.

44. Collison KS, Maqbool Z, Inglis AL et al. (2010): Effect of dietary monosodium glutamate on HFCS-induced hepatic steatosis: expression profiles in the liver and visceral fat. Obesity (Silver Spring) 18(6):1122- 1134.

45. Onyema OO, Farombi EO, Emerole GO et al. (2006): Effect of vitamin $\mathrm{E}$ on monosodium glutamate induced hepatotoxicity and oxidative stress in rats. Indian J. Biochem. Biophys., 43 (1): 2024.

46. Latha $B$ and Babu M (2001): The involvement of free radicals in burn injury: a review. Burns 27(4): 309- 317.

47. Buffon A, Santini SA, Ramazzotti V et al. (2000): Large, sustained cardiac lipid peroxidation and reduced antioxidant capacity in the coronary circulation after brief episodes of myocardial ischemia. J. Am. Coll. Cardiol., 35(3): 633639.

48. Halliwell B (1989): Oxidant and the central nervous system: some fundamental questions. Is oxidant damage relevant to Parkinson's disease, Alzheimer's disease, traumatic injury or stroke?. Acta. Neurol. Scand., 126 (Suppl.): 23133 .

49. Coyle JT and Puttfarcken $P$ (1993): Oxidative stress, glutamate, and neurodegenerative disorders. Science 262: 689- 695.
50. Egbuonu AC, Obidoa O, Ezeokonkwo CA et al. (2009): Hepatotoxic effects of low dose oral administration of monosodium glutamate in male albino rats. African J. of Biotechnology 8 (13): 30313035.

51. Vinodini NA, Nayanatara AK, Ramaswamy C et al. (2010): Study on evaluation of monosodium glutamate induced oxidative damage on renal tissue on adult Wistar rats. J. of Chinese Clinical Medicine 5(3): 144- 147.

52. Farombi EO and Onyema $O O$ (2006): Monosodium glutamateinduced oxidative damage and genotoxicity in the rat: Modulatory role of vitamin $\mathrm{C}$, vitamin $\mathrm{E}$ and quercetin. Human and Experimental Toxicology 25(5): 251- 259.

53. Manivasagam $T$ and Subramanian P (2004): Influence of monosodium glutamate on circadian rhythms of lipid peroxidation products and antioxidants in rats. Ital. J. Biochem., 53(1): 23- 27.

54. López-Pérezet SJ, UreñaGuerrero ME and MoralesVillagrán A (2010): Monosodium glutamate neonatal treatment as a seizure and excitotoxic model. Brain Research 1317: 246- 256.

55. Nardelli TR, Ribeiro RA, Balbo SL et al. (2011): Taurine prevents fat deposition and ameliorates plasma lipid profile in monosodium glutamate-obese rats. Amino Acids 41(4): 901908. 
56. Pardridge WM (1979):

Regulation of amino acids availability to brain: selective control mechanisms for glutamate. In Filer LJ, Garratini S, Kare MR, Reynolds WA \& Wurtman RJ (Eds.). Glutamic Acid: Advances in Biochem. and Physiology Raven. New York 125-138.

57. Fonnum F (1984): Glutamate: a neurotransmitter in mammalian brain. J. Neurochem., 42(1): 111.
58. Torii K, Takasaki $Y$, Iwata $S$ et al. (1981): Changes in blood osmolarity. Electrolytes and metabolites among adult rats treated with a neurotoxic dose of MSG. Life Sci., 28(25): 28552864.

59. Sepúlveda AC, Enríquez MM, Arellanes RR et al. (2009): Neonatal monosodium glutamate administration increases aminooxyacetic Acid (AOA) susceptibility effects in adult mice. Proc. West Pharmacol. Soc., 52: 72-74.

$$
\begin{aligned}
& \text { دراسة عن بعض التغيرات البيوكيميائية فى مخ ودم فئران التجارب الناتجة } \\
& \text { عن إعطاء أحادى جلوتامات الصوديون فيوم } \\
& \text { أبين عبل الفتاح وجيه }
\end{aligned}
$$

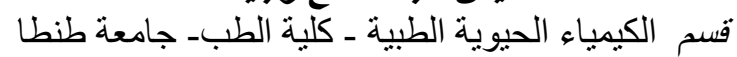

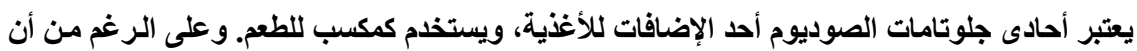




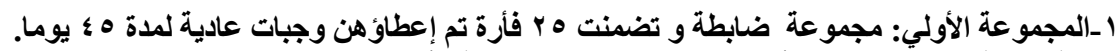

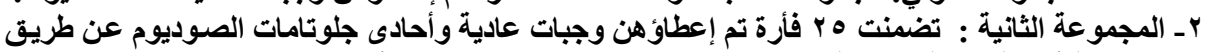

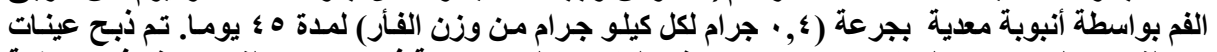

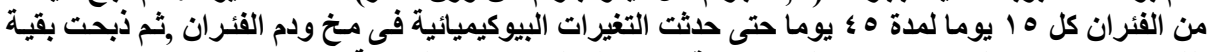

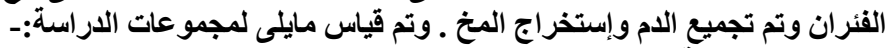

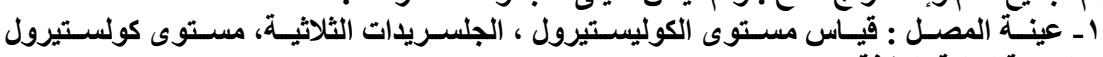

البروتينات الاهنية|لعالية الكثافة فئة

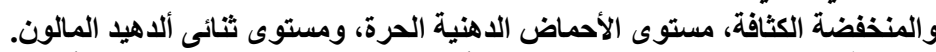

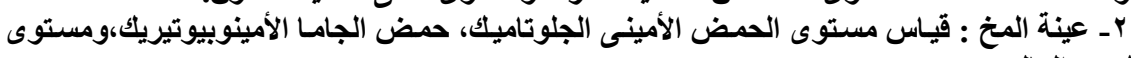
ثنائى ألاهيد ألمالون. ب- إختبار الإستجابة للجلوكوز: عن طريق إستخدام جهاز اللمسة الواحدة عن طريق نقطة دم من ذيل الفئران أثناء الحياة. وقد أسفرت الاراسة عن النتاءئج الآنتية:

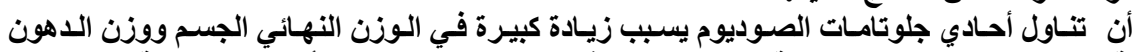

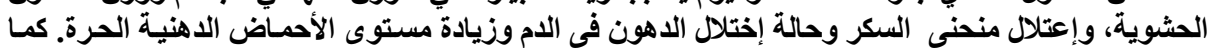

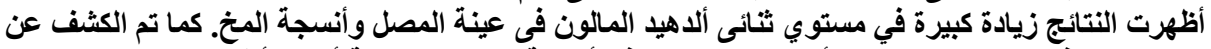

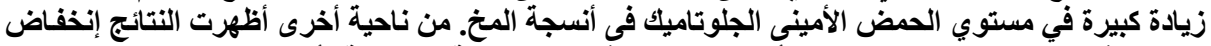

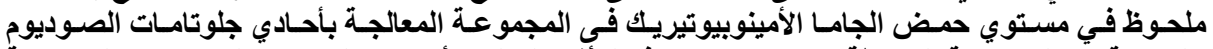

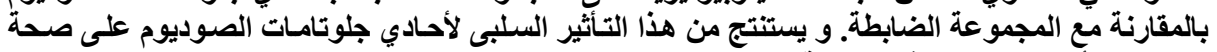

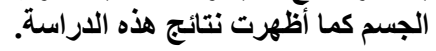

